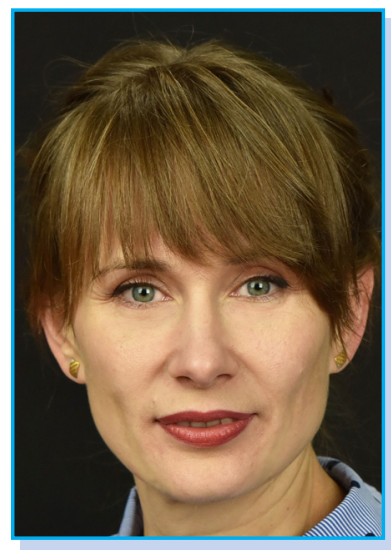

Людмила Усик - кандидат філологічних наук, доцент кафедри іноземних мов Черкаського державного технологічного університету, м. Черкаси, Україна.

Коло наукових інтересів: викладання іноземних мов у закладах вищої освіти, методика викладання іноземної мови за професійним спрямуванням для студентів нефілологічних спеціальностей, актуальні питання порівняльно-історичного та типологічного мовознавства, когнітивна лінгвістика та когнітивно-ономасіологічні дослідження.

(B) luda.usyk@gmail.com

iD https://orcid.org/0000-0002-3306-2641

Вікторія Чорна
старший викладач кафедри мовних
дисциплін Харківського національного
аграрного університету імені В. В. До-
кучаєва, м. Харків, Украӥна. Коло наукових інтересів: методика викладання іноземної мови студентам немовних спеціальностей, викладання зарубіжної літератури в середній школі, поетика сучасного англомовного історичного детективу, інтермедіальний та інтертекстуальний простір сучасного англо-американського ретродетективу.

viktoriachornaya9@gmail.com

https://orcid.org/0000-0002-7288-9043
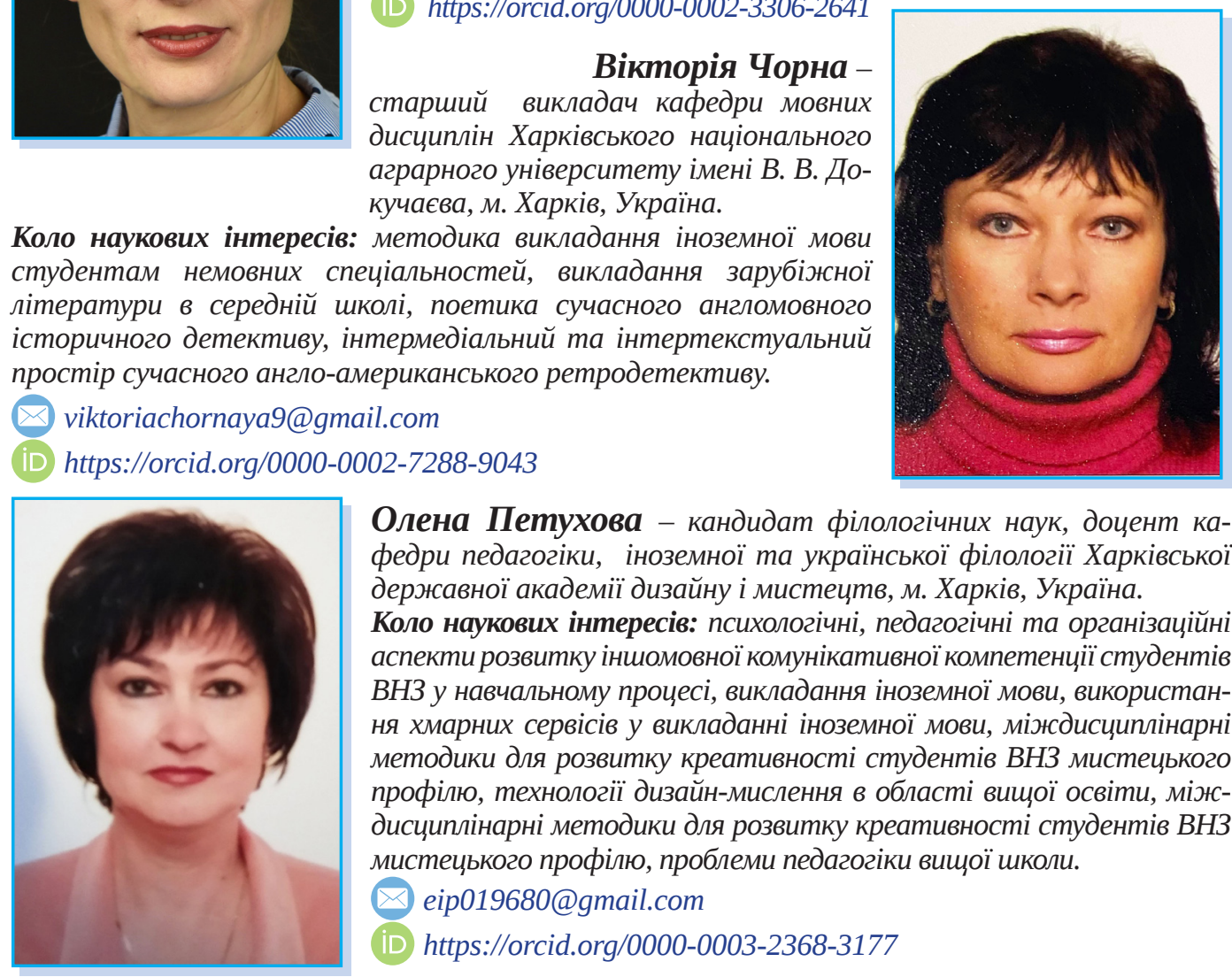

Олена Петухова - кандидат філологічних наук, доцент кафедри педагогіки, іноземної та української філології Харківської державної академії дизайну і мистецтв, м. Харків, Україна.

Коло наукових інтересів: психологічні, педагогічні та організаційні аспекти розвитку іншомовної комунікативної компетенції студентів ВНЗ у навчальному процесі, викладання іноземної мови, використання хмарних сервісів у викладанні іноземної мови, міждисциплінарні методики для розвитку креативності студентів ВНЗ мистецького профілю, технології дизайн-мислення в області вищої освіти, міждисциплінарні методики для розвитку креативності студентів ВНЗ мистецького профілю, проблеми педагогіки вищої школи.

eip019680@gmail.com

(iD) https://orcid.org/0000-0003-2368-3177

УДК 378.016:811.111]:005.336.2

https://doi.org/10.32405/2411-1317-2021-3-51-57

\title{
ФОРМУВАННЯ ПРОФЕСІЙНОЇ КОМПЕТЕНТНОСТІ СТУДЕНТІВ У ПРОЦЕСІ ВИВЧЕННЯ АНГЛІЙСЬКОЇ МОВИ ЗА ПРОФЕСІЙНИМ СПРЯМУВАННЯМ
}

У статті досліджено іншомовну професійну компетентність студентів у процесі вивчення англійської мови за професійним спрямуванням. Розглянуто вітчизняний та європейський досвід діагностики іншомовної професійної компетентності студентів у процесі вивчення англійської 
мови за професійним спрямуванням. Детально проаналізовано професійну компетентність студентів. Важливим є оцінювання рівня професійної компетентності студентів у процесі вивчення англійської мови за професійним спрямуванням. Висвітлено теоретичні та методологічні аспекти діагностики іншомовної професійної компетентності студентів у процесі вивчення англійської мови за професійним спрямуванням.

Ключові слова: діагностика, іншомовна професійна компетентність, процес вивчення англійської мови, професійне спрямування.

Постановка проблеми. Сьогодні, у трансформаційному суспільстві, студенти здобувають професію в умовах постійних відкриттів, нових очікувань, зміни пріоритетів розвитку всіх сфер культурного та соціально-економічного життя. Орієнтація на приєднання країни до європейського співтовариства передбачає певні вимоги до фахівців усіх галузей, однією з таких вимог є вільне володіння іноземними мовами. Розширення контактів міжнародної співпраці, залучення іноземних інвестицій, створення нових спільних підприємств тощо потребує модернізації сучасної освіти, перш за все, упровадження в освітню парадигму підходу професійної компетентності, який забезпечить студентів теоретичними знаннями, практичними навичками, особистим та професійним розвитком. Сьогодні володіння іноземною мовою на професійному рівні, вміння спілкуватися у бізнесі та науці $€$ передумовою успішного кар'єрного зростання випускників.

Аналіз останніх публікацій за проблематикою. Проблеми сутності базових компетенцій, їх формування у майбутніх фахівців вивчала плеяда вчених. Н. Гончарова розглядала професійну компетентність учителя у системі навчання STEM, Д. Демченко досліджував формування професійної іншомовної компетентності майбутніх юристів засобами іноземної мови у фаховій підготовці, В. Доній - проблеми сутності основних компетентностей, їх формування у майбутніх фахівців, Ю. Ємельянов вивчав зміст комунікативної компетентності. В. Байденко, О. Зеєр, Н. Кузьміна - аналізували зміст поняття «професійна компетентність»: В. Байденко виокремив поняття «компетентності» й «компетенції», «компетентнісного підходу», «професійної компетентності»; О. Зеєр аналізує співвідношення «компетентності» й «компетенції»; Н. Кузьміна розглядає компетентність як сукупність психологічних знань, умінь, навичок, необхідних для успішного навчання і розвитку особистості. Висвітлення проблем професійно орієнтованого викладання іноземних мов знайшло відображення у працях зарубіжних учених. Е. Брюстер вважає, що набуття життєво важливої компетентності $\epsilon$ запорукою успішної професійної діяльності майбутнього педагога. Х. Гедерер розглядає формування професійної іншомовної компетентності. Окремі аспекти професійно орієнтованого навчання розглядаються вітчизняними вченими: Л. Кнодель висвітлює інновації у формуванні іншомовної компетентності, О. Коваленко - сутність і компоненти професійної компетентності вчителя української мови та літератури, О. Кузнєцова - значення педагогічної практики у формуванні професійної компетентності майбутніх учителів початкових класів.

Однак, незважаючи на велику кількість наукових праць з теоретичних та практичних аспектів діагностики іншомовної професійної компетентності студентів у процесі вивчення англійської мови за професійним спрямуванням, деякі важливі аспекти залишаються невирішеними, а саме: визначення поняття «іншомовної професійної компетентності» залишається суперечливим.

Вищезазначені наукові роботи є фундаментальною науковою основою для діагностики іншомовної професійної компетентності студентів у процесі вивчення англійської мови за професійним спрямуванням. Однак низка проблем, пов’язаних з розробкою та впровадженням іншомовної професійної компетентності студентів у процесі вивчення англійської мови за професійним спрямуванням, залишається не повністю вирішеною, тому існує потреба у детальному їх вивченні. Саме важливість та значимість цих питань призвели до вибору теми, постановки цілей та завдань дослідження.

Мета статті: здійснити теоретичний аналіз та емпіричне дослідження іншомовної професійної компетентності студентів у процесі вивчення англійської мови за професійним спрямуванням.

Для досягнення мети дослідження необхідно вирішити наступні завдання:

- дослідити іншомовну професійну компетентність студентів у процесі вивчення англійської мови за професійним спрямуванням; 
- розглянути вітчизняний та європейський досвід діагностики іншомовної професійної компетентності студентів у процесі вивчення англійської мови за професійним спрямуванням;

- детально проаналізувати професійну компетентність студентів;

- здійснити оцінювання рівня професійної компетентності студентів у процесі вивчення англійської мови за професійним спрямуванням.

Виклад основного матеріалу дослідження. На сучасному етапі розвитку суспільства загалом і освіти зокрема компетентність особистості надзвичайно актуальна і важлива у самореалізації особистості. Використання терміна компетентність на державному рівні, а також його закріплення в офіційних документах свідчить, що процес формування та розвитку компетентностей тих, хто навчається, $є$ пріоритетним для функціонування системи освіти.

Терміни компетентність та компетентні походять від слова компетентний, що означає здатність щось робити або вирішувати відповідно до своїх знань чи повноважень. Компетентність визначається як здатність робити щось якісно або ефективно [7]; це сфера взаємозв’язку, яка існує між знаннями та діями в людській практиці. Компетентність - це набуті якості особистості та мінімальний досвід у певній галузі [4].

Сучасний фахівець - це продукт самотворення, суб’єктивного бажання особистості вчитися, самостійного набуття знань, свідомої орієнтації на самоконтроль, саморозвиток та активність у всіх сферах. Усе це - результат академічної компетентності студента, набутої під час навчання у вищому навчальному закладі, адже саме там виявляються його здібності та здатність до навчання. Однією зі складових академічної компетентності студентів немовних спеціальностей є знання іноземних мов, що дозволяє студенту працювати з різними освітніми та науковими джерелами, довідниками, професійною інформацією тощо; вести ділове листування, ефективно працювати з комп’ютером, знаходити інформацію в мережі інтернет, бібліотеках закордонних університетів, базах даних наукових праць, робити презентації в режимі Power Point, спілкуватися з колегами з-за кордону, отримувати нові знання завдяки знанню іноземної мови тощо.

Знання іноземних мов відіграє значну роль у формуванні професійної компетентності випускників немовних спеціальностей. Однак слід мати на увазі, що професійна компетентність не є сталою цінністю: вона постійно змінюється під впливом зовнішніх факторів, науково-технічного прогресу тощо. Не існує встановленого переліку компетенцій, оскільки кожна професія має унікальний набір здібностей, властивих лише їй, без оволодіння якими процес адаптації та подальше професійне виконання своїх обов’язків може спричинити значні проблеми [3, с. 24].

Наративна характеристика сфери професійної діяльності фахівця дозволяє виділити такі професійні компетенції:

- предметна компетентність (комплекс загальнотеоретичної підготовки та виробничої практики);

- комунікативна компетентність (професійно орієнтована).

Вивчення іноземних мов на основі професійної орієнтації сприяє формуванню навичок майбутнього спеціаліста реалізовуватись у спілкуванні, налагоджувати ділові контакти, вивчати іноземні джерела, аналізувати сучасні наукові досягнення, вдосконалювати навички та представляти ідеї професійній спільноті. Професійна комунікативна компетентність розвиває такі професійні якості, як самостійність, самоконтроль, відповідальність, творче мислення, професіоналізм.

Професійно орієнтоване викладання іноземної мови передбачає вивчення іноземної мови студентами в сучасному контексті особливостей майбутньої професії. Звичайно, такий підхід повинен враховувати особисті якості студентів. Уміле поєднання професійних та мовних знань та навичок допоможе випускникам нелінгвістичних спеціальностей досягти рівня іноземної мови професійно орієнтованої комунікативної компетентності, що дозволить їм використовувати іноземну мову у професійній діяльності на рівні міжнародних стандартів.

Враховуючи високі вимоги до випускників немовних спеціальностей з точки зору професійних та практичних знань іноземних мов, актуальними стають питання розробки організаційно-педагогічних механізмів навчання студентів іноземних мов для подальшого його використання з професійною метою. 
Загальнотеоретичні знання, отримані студентами під час навчання у вищому навчальному закладі, будуть ефективними та значними у поєднанні з професійною практикою. Тому в процесі навчання необхідно реалізовувати завдання та завдання навчальної дисципліни, враховувати інтереси та мотивацію студентів. Викладач повинен підбирати навчальний матеріал таким чином, щоб його професійна специфіка та мовна компетентність студентів працювали для задоволення майбутніх професійних потреб. Усебічне засвоєння загальних та професійних (спрямованих на практичну професійну діяльність) компонентів сприятиме повноцінному та успішному здійсненню завдань та цілей [4, с. 21].

Професійна спрямованість діяльності вимагає інтеграції дисципліни «Іноземна мова» 3 профільними дисциплінами; це ставить перед учителем іноземної мови завдання навчити майбутнього спеціаліста на основі міждисциплінарних зв' язків користуватися іноземною мовою як засобом систематичного поповнення своїх професійних знань та як способом розвитку професійних навичок; передбачає використання форм і методів навчання, що забезпечують формування необхідних професійних навичок майбутнього фахівця. Однією з головних умов викладання професійної іноземної мови є взаємодія викладачів мовної та профільної кафедр на всіх етапах навчання, включаючи спільне навчання.

Комунікативна компетентність насамперед передбачає набуття лексичної компетентності, без якої неможливе повноцінне спілкування. Викладачі вищих навчальних закладів, науковці, методисти вивчають роль лексичних механізмів у рецептивних та продуктивних видах мовленнєвої діяльності, розробляють типи вправ та складають словники-мінімуми професійної лексики. Однак ефективне вирішення цієї проблеми можливе лише за умови постійного вдосконалення такої роботи, пошуку та упровадження нових методів навчання студентів немовним спеціальностям професійного лексичного матеріалу.

Аналіз проблеми визначення етапів формування іншомовної лексичної компетентності базується на позиції, що процес оволодіння іншомовною лексикою починається з набуття знань про лексику та формування початкових (лексичних) навичок і закінчується розвитком вторинних (мовленнєвих) навичок [2]. Ю. Пассов [5] виділяє такі етапи набуття лексичних навичок: спочатку формуються навички роботи з лексичним матеріалом, потім відбувається етап вдосконалення навичок і лише після цього - етап розвитку навичок оперування лексичними одиницями у мовленнєвій діяльності.

Одним із організаційно-педагогічних факторів, який спонукає студентів до професійної діяльності та позитивно впливає на бажання вільно володіти іноземною мовою, є моделювання професійно орієнтованих ситуацій. Такий підхід передбачає вибір продуктивних методів організації навчальновиховного процесу з урахуванням особистих якостей учнів, їх інтересів та планів на майбутнє.

Професійне викладання іноземної мови передбачає такі елементи:

1. Набуття загальнотеоретичних мовних знань та навичок у процесі засвоєння змісту розділів «Фонетика», «Граматика», «Лексикологія», «Стилістика», «Професійна термінологія» та інших, що сприяє подальшому розвитку читання, письма, слухання, мовленнєвих навичкок.

2. Набуття комунікативних умінь та навичок відповідно до видів мовленнєвої діяльності (говоріння, аудіювання, читання, письмо) на основі загальної та професійної лексики. Як монологічне, так і діалогічне мовлення розвивають такі якості, як здатність обмінюватися професійною інформацією, представляти свої ідеї, відстоювати власну думку тощо. Прослуховування професійних навичок допомагає подолати страх безпосереднього спілкування з іноземними експертами, зрозуміти на слух суть висловлювань, швидше адаптуватися до сприйняття реальної ситуації. Професійно орієнтоване навчання-читання формує відповідні навички ознайомлення як із загальними текстами, так і з професійною літературою. Нарешті, навчання письму є одним з найважливіших структурних елементів комунікативної компетентності, розвиває здатність до професійного ділового листування, професійного художнього перекладу фахової літератури, професійного ведення ділової документації.

Т. Вахрушева наголошує на необхідності використання у цьому процесі активних методів навчання, оскільки це передбачає не викладання готових знань та їх відтворення, а самостійне засвоєння студентами матеріалу в процесі активної пізнавальної діяльності. Дослідниця вважає, що активні методи навчання - це навчальна діяльність. Саме в активній діяльності, спрямованій викладачем, студенти здобувають необхідні знання, набувають навичок та вмінь професійної діяльності, у них розвиваються творчі здібності тощо. Слід підкреслити, що основою активних методів є діалогічне 
спілкування між викладачем та студентами, між студентами, що важливо, оскільки у процесі діалогу розвиваються комунікативні навички, уміння колективно вирішувати проблеми i, що найголовніше, розвивається мова та мовлення [2, с. 24].

До активних методів навчання (за Т. Вахрушевою) належать:

- візуалізована лекція, яка використовується для кращого сприйняття інформації;

- тренінг, у рамках якого кожному учаснику стає доступним не тільки досвід та знання тренера, але й досвід та знання інших учасників. Крім того, тренінг передбачає використання інших активних методів навчання: мінілекції, рольові ігри, робота в команді, що робить навчання більш ефективним;

- «мозковий штурм», який використовується для вирішення конкретної проблеми учасниками: вони висловлюють свої ідеї та пропозиції - як результат, це сприяє розвиткові творчого мислення учасників;

- «мікрофон», коли говорить лише людина з уявним мікрофоном, відповіді мають бути стислими і швидкими, їх не коментують і не оцінюють;

- «ток-шоу», в якому група з 3-5 осіб обговорює заздалегідь обрану тему в аудиторії. Це дає можливість чітко висловити різні точки зору на певну тему, тому основні учасники дискусії повинні бути добре підготовленими.

Найважливішими факторами забезпечення іншомовної професійної компетентності студентів у процесі вивчення англійської мови за професійним спрямуванням у сфері діагностики економічної безпеки підприємства є науково-технічний прогрес, а також інноваційні процеси в компаніях. Важливо своєчасно знайти найбільш раціональні джерела фінансування інноваційного розвитку компаній.

ПРИНЦИПИ РЕАЛІЗАЦЇ̈ МЕХАНІЗМІВ УПРАВЛНННЯ ПНШОМОВНОЮ ПРОФЕСІЙНОЮ КОМПЕТЕНТНІСТЮ СТУДЕНТІВ У ПРОЦЕСІ ВИВЧЕННЯ АНГЛІЙСЬКОӤ МОВИ ЗА ПРОФЕСІЙНИМ СПРЯМУВАННЯМ

\begin{tabular}{|c|c|}
\hline СИСТЕМНОСТІ & $\begin{array}{l}\text { формування відкритої, динамічної імовірнісного характеру системи } \\
\text { управління безпекою }\end{array}$ \\
\hline АДАПТИВНОСТІ & $\begin{array}{l}\text { підтримання балансу зовнішніх, сформованих ринковим середовищем, } \\
\text { і внутрішніх можливостей розвитку }\end{array}$ \\
\hline САМООРГАНІЗАЦ & самостійне забезпечення підтримки обміну різними видами ресурсів \\
\hline ДИНАМІЧНОСТІ & $\begin{array}{l}\text { динамічне приведення у відповідність цілей і спонукальних мотивів } \\
\text { діяльності }\end{array}$ \\
\hline ЕФЕКТИВНОСТІ & $\begin{array}{l}\text { зростання прибутку, розширення масштабів виробництва і можливо- } \\
\text { стей нагромадження капіталу, підвищенням конкурентоспроможності }\end{array}$ \\
\hline КЕРОВАНОСТI & $\begin{array}{l}\text { забезпечення відповідності фактичного стану процесу бажаному, } \\
\text { запланованому стану після реалізації системної трансформації }\end{array}$ \\
\hline САМОРОЗВИТКУ & $\begin{array}{l}\text { самостійне забезпечення умов функціонування підприємства } \\
\text { відповідно до прийнятої стратегії розвитку }\end{array}$ \\
\hline
\end{tabular}

Рис. 1.1 - Принципи діагностики економічної безпеки підприємства (Джерело: розроблено автором*)

Постійне вдосконалення механізмів моделювання та управління процесом діагностики економічної безпеки компанії гарантує компанії стабільне функціонування та розвиток. У цьому випадку настанова буде ефективною та стійкою в ринковому середовищі та надасть компанії конкурентну перевагу [6, с. 24]. 
Отже, ефективність компанії та її існування, особливо за нестабільних умов трансформаційної економіки, значною мірою залежать від системи економічної безпеки. Під економічною безпекою компанії розуміють стан ефективного використання ії̈ ресурсів (економічний потенціал) та існуючі ринкові можливості, що запобігають внутрішнім та зовнішнім загрозам, забезпечують ії довгострокове існування та стійкий розвиток відповідно до обраної місії [1, с. 21].

Система управління компанією повинна постійно чекати загроз зовнішнього та внутрішнього середовища та відповідати на них належним чином. Тому необхідний систематичний метод діагностики економічної безпеки компанії.

Результати діагностики та оцінки рівня складових економічної безпеки повинні стати основою для розробки комплексу заходів, спрямованих на протидію загрозам та підвищення рівня економічної безпеки компанії.

Висновки і перспективи подалыших досліджень. Аналіз наукових джерел та актуальної проблеми підготовки студентів немовних спеціальностей до майбутньої професійної діяльності дозволяє зробити висновок, що формування професійної іншомовної комунікативної компетентності студентів немовних спеціальностей вимагає дотримання цілей та планів підготовки, а саме: система навчання повинна бути спрямована на задоволення практичних потреб; підготовка майбутніх фахівців є комплексною, теоретичною та практичною.

Основою ефективного викладання іноземних мов має стати міждисциплінарна взаємодія викладачів та тісний взаємозв'язок між змістом та підходами до викладання загальнотеоретичних, професійних дисциплін та дисципліни «Іноземна мова професійної спрямованості». В активній діяльності, спрямованій викладачем, студенти здобувають необхідні знання, набувають навичок та вмінь професійної діяльності, у них розвиваються творчі здібності тощо.

Ми визначили, що одним із організаційно-педагогічних факторів, який спонукає студентів до професійної діяльності та позитивно впливає на бажання вільно володіти іноземною мовою, є моделювання професійно орієнтованих ситуацій. Такий підхід передбачає вибір продуктивних методів організації навчально-виховного процесу з урахуванням особистих якостей учнів, їх інтересів та планів на майбутнє.

Виявлені та теоретично обгрунтовані організаційно-педагогічні фактори (організація навчальної діяльності; зміст навчального матеріалу; міжособистісні стосунки викладачів та учнів; створення професійних ситуацій на уроках іноземної мови; високий рівень професійної компетентності вчителів) та умови мотивації студентів до вивчення іноземної мови (оптимальне планування структури та змісту організації вивчення дисципліни; врахування психолого-педагогічних факторів, що впливають на процес формування мотивації до вивчення іноземної мови; визначення ефективних принципів, форм, методів та засобів навчання тощо).

Комунікативна компетентність іноземних мов забезпечить випускникам університетів можливість повноцінно працювати не лише з вітчизняними, а й світовими джерелами інформації, знайомитись з новими технологіями та тенденціями певної галузі, встановлювати контакти з іноземними партнерами у процесі професійної діяльності та сприяти швидшій адаптації у світовому професійному суспільстві, успішній діяльності в ньому.

\section{Використані джерела}

[1] Ю. М. Бахрамов, «Финансовый менеджмент», Москва, Россия, Лань, 2006.

[2] О. О. Гетьман, «Економічна діагностика: навч. посіб. для студ. ВНЗ», Київ, Україна, Центр навчальної літератури, 2007.

[3] Т. О. Загорна, «Економічна діагностика: навч. посіб», Київ, Україна, Центр навчальної літератури, 2007.

[4] Ю. М. Коваленко, «Теорії портфеля крізь призму сучасних кризових явищ», Київ, Україна, 2008.

[5] Є. О. Малашинська, «Стан та перспективи розвитку фондового ринку України», Проблеми економічної освіти та наукового прогресу, Кривий Ріг, Україна, Мінерал, 2005.

[6] «Проблема Кігеля В.Р. Марковиці: оновлена формулювання, аналітичне рішення, межі та можливі сфери використання аналітичного методу», Київ, Україна, Університет економіки та права «КРОК», 2013.

[7] А. А. Турило, «Система критеріїв і показників оцінювання безпеки підприємств у процесі інноваційного розвитку», Актуальні проблеми економіки, 2014. 


\section{References}

[1] Yu. M. Bakhramov, «Fsnansovyy menedzhment», Moskva, Rossyya, Lan’, 2006. (in Russian)

[2] O. O. Het’man, «Ekonomichna diahnostyka: navch. posib. dlya stud. VNZ», Kyyiv, Ukrayina, Tsentr navchal'noyi literatury, 2007. (in Ukrainian).

[3] T. O. Zahorna, «Ekonomichna diahnostyka: navch. posib», Kyyiv, Ukrayina, Tsentr navchal’noyi literatury, 2007. (in Ukrainian).

[4] Yu. M. Kovalenko, «Teoriyi portfelya kriz’ pryzmu suchasnykh kryzovykh yavyshch», Kyyiv, Ukrayina, 2008. (in Ukrainian).

[5] Ye. O. Malashyns’ka, «Stan ta perspektyvy rozvytku fondovoho rynku Ukrayiny», Problemy ekonomichnoyi osvity ta naukovoho prohresu, Kryvyy Rih, Ukrayina, Mineral, 2005. (in Ukrainian).

[6] «Problema Kihelya V.R. Markovytsi: onovlena formulyuvannya, analitychne rishennya, mezhi ta mozhlyvi sfery vykorystannya analitychnoho metodu», Kyyiv, Ukrayina, Universytet ekonomiky ta prava «KROK», 2013. (in Ukrainian).

[7] A. A. Turylo, «Systema kryteriyiv i pokaznykiv otsinyuvannya bezpeky pidpryyemstv u protsesi innovatsiynoho rozvytku», Aktual'ni problemy ekonomiky, 2014. (in Ukrainian).

Lyudmyla Usyk, PhD (Philology), Associate Professor of the Department of Foreign Languages, Cherkasy State Technological University, Cherkasy, Ukraine.

Victoria Chorna, Senior Lecturer, Department of Language Disciplines, VV Dokuchaev Kharkiv National Agrarian University, Kharkiv, Ukraine.

Olena Petukhova, PhD (Philology), Associate Professor of the Department of Pedagogy, Foreign and Ukrainian Philology, Kharkiv State Academy of Design and Arts, Kharkiv, Ukraine.

\section{FORMATION OF PROFESSIONAL COMPETENCE OF STUDENTS IN THE PROCESS OF LEARNING ENGLISH IN A PROFESSIONAL ORIENTATION}

This paper presents the foreign language professional competence of students in the process of learning English for professional purposes. Domestic and European experience of diagnostics of foreign language professional competence of students in the process of studying English for professional purposes is considered. The professional competence of students is analyzed in detail. It is important to assess the level of professional competence of students in the process of learning English in a professional direction.

In this article we highlight the theoretical and methodological aspects of the diagnosis of foreign language professional competence of students in the process of learning English for professional purposes.

We determined that the basis of effective teaching of foreign languages should be the interdisciplinary interaction of teachers and close relationship between the content and approaches to the teaching of general authentic, professional disciplines and disciplines "Foreign language of professional orientation".

Thanks to the interest in foreign languages in the present-day world, the attention of the scientific community has shifted from the study of the peculiarities of literary foreign language to the study of the language used in real communication of specialists in certain industries.

The specificity of foreign language professional competence is determined by professional orientation. By studying professionally-oriented literature and receiving new information from it, students expand their professional competence. The discipline, being theoretical in form, contains a huge potential of knowledge that can expand the professional worldview of the future specialist and make a significant contribution to its formation as a skilled worker.

Foreign language professional competence can be embodied in activities that include such language activities as obtaining information from the Internet, presentation of material, written and oral exchange of information (including e-mail), expression of opinion, discussion, etc.

Key words: diagnostics; foreign language professional competence; process of learning English; professional orientation. 